\title{
PANDANGAN STAKEHOLDER PARIWISATA TENTANG HALAL TOURISM DAN BRANDING YOGYAKARTA
}

\author{
Aswad Ishak \\ Dosen Prodi Ilmu Komunikasi Universitas Muhammadiyah Yogyakarta
}

\begin{abstract}
Pariwisata mampu mendatangkan pendapatan yang besar bagi pemerintah. Potensi wisata sangat banyak yang dapat digali dan dikembangkan. Salah satu potensi wisata yang sedang dikembangang dan memiliki ceruk pasar yang khas adalah wisata halal. Kesadaran pentingnya kehalalan dalam dunia pariwisata masih ditanggapi secara beragam. Oleh karenanya penelitian mengenai halal tourism di mata stakeholder pariwisata di Yogyakarta perlu dilakukan dan dimaksudkan untuk mendapatkan gambaran pandangan dan pengertian konsep halal tourism yang dipahami oleh pemangku kepentingan pariwisata di Yogyakarta. Disamping itu, penelitian ini dilakukan juga ditujukan untuk mengetahui pemahaman serta usulan branding Yogyakarta menurut stakeholder terkait. Obyek penelitian ini adalah pandangan para pemangku kepentingan pariwisata Yogyakarta tentang halal tourism dan branding. Penelitian ini menggunakan metode kualitatif yang memaparkan bagaimana pendapat, pandangan dan usulan yang diberikan oleh stakeholder pariwisata Yogyakarta terkait dengan obyek penelitian meliputi dinas pariwisata kota yogyakarta, hotel, wisatawan, dan media massa. Hasil penelitian menunjukkan bahwa pemahahaman mengenai wisata halal masih belum seragam. Masing-masing pelaku wisata belum menemukan konsep yang sama tentang penerapan wisata halal. Hal ini dapat menyulitkan dalam pengembangan pariwisata halal di Yogyakarta. Selain itu wisata halal perlu sinkron dengan konsep kampanye pariwisata yang dirancang sebelumnya. Perlu edukasi yang menyeluruh dan mendalam mengenai wisata halal kepada setiap pemangku kepentingan pariwisata Yogyakarta.
\end{abstract}

Keywords: Halal tourism, branding, stakeholder pariwisata

\begin{abstract}
Tourism is able to bring huge revenues to the government. Very much tourism potential that can be explored and developed. One of the tourism potentials that is being developed and has a unique market niche is halal tourism. Important awareness about the world in the world is still responded to diverse. Therefore research on halal tourism in the eyes of stakeholders in Yogyakarta needs to be done and discussed to get an understanding of and understand the concept of halal tourism discussed by tourism stakeholders in Yogyakarta. In addition, this study was also conducted to learn to understand and recommend Yogyakarta branding according to relevant stakeholders. The object of this research is the opinion of stakeholders about Yogyakarta about halal tourism and branding. This study uses qualitative methods that describe the opinions, views and opinions provided by Yogyakarta stakeholders related to the Yogyakarta tourism service research object, hotels, tourists, and mass media. The results showed that halal about halal tourism is still not uniform. Each of them supports that they have not found the same concept of implementing halal tourism. This can complicate the development of tourism in Yogyakarta. In addition, halal tourism needs to be in sync with the concept of a tourist campaign that was previously designed. Need complete and complete education about halal tourism for every tourist in Yogyakarta.
\end{abstract}

Keywords: halal tourism, branding, tourism stakeholders 


\section{INTRODUCTION}

Sektor pariwisata dalam beberapa tahun terakhir ini menjadi sorotan berbagai macam pihak. Industri pariwisata di Indonesia mampu menggerakkan roda perekonomian di tingkat lokal, regional ataupun secara nasional. Pergerakan ekonomi di dari sektor pariwisata ini mampu mendorong dan membangkitkan tingkat kesejahteraan masyarakat. Sektor pariwisata akan melibatkan bisnis mulai dari hulu hingga hilir. Industri jasa transportasi, akomodasi, pertunjukan, oleh-oleh dan souvenir, dan lain sebagainya menjadi roda gigi yang saling terkait. Cakupan yang dijangkau sangat massif mulai dari small medium enterprise (SME) sampai industri skala besar dapat terlibat di dalamnya.

Secara nasional, regional, maupun lokal, berbagai macam penemuan dan pengembangan obyek kunjungan wisata baru telah dilakukan eksplorasi baik itu yang memanfaatkan potensi alam, budaya, sosial kemasyarakatan, maupun obyek wisata buatan seperti taman bermain dan sejenisnya. Masing-masing daerah atau kota berupaya mempersiapkan sarana dan prasarana yang menunjang datangya wisatawan baik domestik ataupun mancanegara. Yogyakarta sebagai destinasi pari wisata kedua di Indonesia setelah Bali menjadi barometer penting bagi pengembangan industri pariwisata. Yogyakarta dengan berbagai usaha dan kreasi untuk mendatangkan wisatawan sebanyak mungkin. Datangnya wisatawan berarti ekonomi daerah menggeliat dan penerimaan negara meningkat.

Salah satu hal penting yang tengah dikembangkan terkait pariwisata ini adalah persoalan wisata halal (halal tourism) karenan diyakini memiliki pangsa pasar yang sangat besar baik di dalam maupun luar negeri. Penanganan mengenai hal tersebut belum tersentuh atau dilakukan dengan baik. Secara domestik Indonesia dengan penduduk muslim mayoritas dengan jumlah tak kurang dari $85 \%$ dari total populasi, menjadikan hal ini sebagai pangsa pasar yang besar. Selain itu, negara di kawasan ASEAN khususnya negara jiran Malaysia dan Brunai Darussalam juga memiliki cukup banyak penduduk yang memeluk Islam. Disamping itu, negara-negara kawasan timur tengah juga menjadi sasaran jangkauan dari wisata halal. Bahkan tak jarang wisatawan non muslim pun tertarik dengan wisata halal ini. Dengan potensi pasar yang besar tersebut perlu didukung pemahaman tentang kriteria wisata halal yang sama untuk setiap stakeholder. Dengan menggunakan konsep wisata halal tersebut maka diyakini akan mampu mendatangkan wisatawan dari beragai kawasan. Pelaksanaan konsep 
tersebut perlu diawali dari pengetahuan atau pemahaman para pelaku sektor pariwisata terhadap persolan dimaksud. Sehingga harapannya akan mampu membumikan dalam setiap aspek dalam halal tourism tersebut dalam menjalankan industri wisata yang dikelolanya. Tanpa ada pemahaman yang memadai tentang konsep wisata halal tersebut maka akan kesulitan dalam mengimlementasikan dalam setiap kegiatan branding yang akan dijalankan nantinya. Sedangkan tanpa branding yang jelas maka akan kesulitan mencapai awareness dan sampai pada perilaku memilih destinasi pariwisata.

Aktifitas branding suatu wilayah atau kota menjadi hal penting bagi calon wisatawan untuk menentukan destinasi wisata tersebut layak atau tidak di dalam daftar agenda kunjungan mereka. Dengan perkembangan teknologi informasi sekarang ini kesadaran orang terhadap aspek kehalalan suatu produk atau jasa makin meningkat. Hal tersebut ditambah lagi dengan semakin membaiknya pertumbuhan ekonomi sehingga konsumsi juga mengalai peningkatan, termasuk dalam hal wisata. Hal inilah yang mendorong pariwisata halal makin menemukan pasar yang tepat dan perlu mendapatkan perhatian serta penganangan yang tepat.

Pada penelitian ini pemilihan Yogyakarta sebagai fokus wilayah kajian karena di Yogyakarta merupakan salah satu daerah destinasi utama kunjungan wisatawan dan sebagai salah satu daerah yang oleh kemeterian pariwisata ditetapkan menjadi daerah wisata halal. Beberapa hotel sudah melakukan klaim sebagai muslin friendly hotel atau bahkan menjadi hotel Syariah sepenuhnya. Dengan tingkat keragaman yang tinggi di Yogyakarta menjadikan semakin memperkuat tentang bagaimana konsep halal tourism dan branding dilakukan.

Bedasar pada uraian latar belakang yang dipaparkan, maka masalah dalam penelitian ini adalah bagaimana pandangan stakeholder pariwisata Yogyakarta tentang konsep halal tourism dan branding Yogyakarta yang harus dilakukan ?

Dalam penelitian ini bertujuan untuk mengetahui pandangan stakeholder pariwisata Yogyakarta tentang konsep halal tourism dan branding Yogyakarta yang harus dilakukan dalam upaya mendatangkan wisatawan.

\section{METHODOLOGY OF RESEARCH}

Penelitian ini termasuk kedalam jenis penelitian deskriptif kualitatif. Penelitian deskriptif menurut Whitney (dalam Nazir, 1988: 63) yaitu penelitian untuk pencarian fakta dengan interpretasi yang tepat. Penelitian ini menggunakan metode studi kasus, metode studi 
kasus adalah memberikan gambaran secara mendetail tentang latar belakang, 2 Tahun 2019 karakter yang khas dari kasus, dari sifat-sifat khas tersebut akan dijadikan suatu hal yang bersifat umum. (Nazir, 1988:66).

Teknik pengumpulan data dalam penelitian ini, peneliti menggunakan cara wawancara kepada stakeholder pariwisata di Yogyakarta yaitu: Dinas Pariwisata Kota Yogyakarta, Hotel Forriz Yogyakarta, AdiTV, dan wisatawan yang mengunjungi Yogyakarta. Data dalam penelitian ini akan dianalisis secara kualitatif. Penelitian kualitatif merupakan suatu prosedur yang menghasilakan data deskriptif berupa kata tertulis, atau lisan orang-orang atau perilaku yang diamati (Moleong, 2001: 103). Selain itu data dianalisis dengan langkahlangkah analisis data : Pengumpulan data, reduksi data, penyajian data, analisis data dan kesimpulan. Teknik yang dilakukan dalam uji validitas data yaitu dengan teknik triangulasi. Menurut Moleong (2001: 178), triangulasi adalah teknik pemeriksaan keabsahan data yang memanfaatkan sesuatu lain diluar data itu untuk keperluan pengecekan atau sebagai pembanding terhadap data itu. Dalam penelitian ini, peneliti mengunakan triangulasi sumber dengan membandingkan atau crosscheck informasi dari satu informan dengan informan lain

\section{RESULT AND DISCUSSION}

\section{Pandangan Stakeholder Tentang Halal Tourism}

Teminologi halal tourism merupakan hal yang baru bagi sebagian besar masyarakat. Hal tersebut menimbulkan pro dan kontra mengenai apa yang dimaksud dengan istilah tersebut, seperti apa penerapannya, perlu tidaknya diterapkan, dan sebagainya. Secara umum masyarakat berangapan bahwa kata halal yang dilekatkan dengan kata pariwisata konotasi atau persepsi yang dimiliki adalah penerapan aturan Islam secara menyeluruh dalam dunia pariwisata. Pandangan ini melihat pelekatan kata dapat memberikan kesan menakutkan. Sementara sebagian kecil yang lain lain melihat bahwa pariwisata halal memberikan rasa aman dan nyaman bagi para wisatawan pada saat mengunjungi obyek wisata yang diminati.

Konsep halal dalam pariwisata sudah mulai dikenal oleh kalangan pelaku wisata. Salah satu pemangku kepentingan pariwsata adalah hotel. Wilayah Yogyakarta sebagai salah satu destinasi wisata utama di Indonesia memiliki banyak hotel yang tersebar di berbagai sudut kota. Salah satu hotel tersebut adaah Forriz. Menurut Kinanti, senior sales and marcomm Forriz hotel menyatakan bahwa "Wisata halal adalah wisata yang pastinya tidak melanggar aturan-aturan atau norma-norma baik agama, sosial, maupun masyarakat ya.. itu 
menurut saya untuk wisata halal'. Berdasar pernyataan inı mengindikasikân bahwa wisata halal sifatnya sangat universal, karena bisa berlaku untuk semua orang. Aturan, agama, sosial, dan masyarakat menjadi dasar dalam pengelolaan bisnis hotel untuk mendatangkan tamu yang berimbas pada kunjungan wisatawan.

Dalam upaya mendapatkan tamu hotel yang memang pangsa pasarnya lebih banyak muslim, maka pihak hotel melakukan serangkaian upaya untuk memenuh kebutuhan para tamu yang menginap di hotelnya. Hotel Forriz menyediakan paket wisata yang sesuai dengan traveler muslim, "Jelas informasinya, yang memang bisa kita berikan. Kemudian di Forriz kita juga punya paket-paket perjalanan wisata dan tour, ya jadi dukungan-dukungan seperti itu yang bisa kita berikan." Hal ini dilakukan sebagai upaya untuk menciptakan relasi yang melekat kuat. Keadaan ini merupakan sebuah cara yang dijalankan melaksanakan fungsi kehumasan untuk kepentingan jangka panjang. Bagi hotel hal ini akan dapat memberikan efek untuk kunjungan menginap selanjutnya di kemudian hari atau dapat berfungsi sebagai storyteller bagi orang lain mengenai hotel tersebut sehingga dapat mengenal keberadaan hotel Forriz.

Sebagai salah satu pelaku wisata yang peduli dengan wisatawan muslim, Forriz hotel juga telah memroses untuk sertifikasi halal. "Oh iya.. kita juga ini.. kita juga menuju sertifikasi halal dan sudah proses..."..Lebih lanjut Kinanti menjelaskan mengenai konsep halal dalam pengelolaan hotel yang telah diajukan

Kalau sertifikasi halal itu emang agak lama ya.. karena setahu saya mulai dari misalnya bahan-bahannya. Dagingnya apa saja yang tidak boleh. Kemudian, halal itu sendiri juga kan dari prosesnya, gitu. Kayak misalnya sapi gelonggongan. Itu kan masuknya kalau tidak salah, nggak halal ya.. karena dia menyiksa si binatang itu sendiri gitu.. jadi ya.. kemarin memang agak lama karena kan ditanya ya ini mengambilnya dari mana? Ini prosesnya bagaimana?

Fasilitas hotel yang disediakan juga mendukung konsep halal yang dibangun. Pihak manajemen hotel melakukan aktifitas branding sebagai penyedia makanan halal di dalam hotel. Kondisi ini dikomunikasikan dengan intensif kepada semua pemangku kepentingan. Hal ini sebagaimana disampaikan dalam kutipan sebagai berikut:

"Iya pasti, kalau di sini tuh udah pasti kalau untuk strategi komunikasi kita akan selalu mencantumkan halal. Tapi memang yah.. kalau saya sih dari segi makanan karena hotel ini sebetulnya semi syariah ya, dalam artian kita di sini.. kalau biasanya hotel kan orang yang berhijab tidak boleh.. kita gak papa pakai hijab..

Selain itu fasilitas lain juga mendukung untuk kebutuhan traveler muslim 
"Sudah ada mushola, mushola nya di bawah.." dalam kamar juga Thelah 2019 tersedia di kamar, terus untuk Al-Qur'an itu kita di beberapa kamar ada, memang tidak semua.. tapi ada di beberapa kamar. Tapi memang kamar-kamar yang Delux, Sweet kayak gitu.. itu kita pasti ada."

Wisata syari'ah dapat dipahami sebagai segala macam kegatan yang didukung oleh berbagai fasilitas dan layanan dalam menunjang pelaksanaan pariwisata baik yang disedikan oleh pemerintah, masyarakat dan pengusaha yang di dalamnya memenuhi kriteria atau ketentuan syari'ah (Janitra, 2017). Lebih jauh tanngapan positif dikemukanan oleh Kinanti mengenai wisata halal. Menurutnya wisata halal memiliki prospek yang bagus untuk dikembangkan. Kehalalalan suatu jasa atau produk menjadi kebutuhan bagi banyak pihak. "Karena menurut saya halal itu sekarang kebutuhannya bukan cuma untuk kaum muslim. Kaum non muslim juga memerlukannya." Pemahaman seperti ini menjadikan potensi modal awal penggerak bagi roda pariwisata halal di Yogyakarta pada masa mendatang.

Untuk wisata halal ini, di Forriz yaa.. kalau saya sih harapannya.. mencari rezeki itu tidak selalu dilakukan dengan segala cara kok. kita bisa melakukan dengan cara yang halal. Tidak perlu haram.. kalau aku statement nya seperti itu.. ya jadi, aku sih setuju untuk wisata halal, seperti ini. Harapan saya adalah semoga ke depan wisata halal yang memang bisa diterima untuk kalangan, itu yang saya harapkan..

Pentingnya hotel Syariah ataupun yang ramah muslim ini jelas sekali karena di Indonesia pangsa pasar wisatawan muslim sangat besar jumlahmya. Pertumbuhan kelas menengah di Indonesia sebagian besar juga umat Islam. Dalam melaksanakan perjalanan wisata para wisatawan muslim ini memerlukan penginapan yang menjamin dirinya dapat melaksanakan ajaran Islam sebagai wujud kepatuhan terhadap agama untuk melaksanakan ibadah (Yuswohadi, 2014). Jika semua fasilitas pendukunf pariwisata ramah dengan muslim maka wisatawan muslim akan senang dan tidak perlu ragu untuk melakukan kunjungan ke suatu destinasi wisata.

Stakeholder penting lain dalam pariwisata adalah para wisatawan itu sendiri. Wisatawan sangat beragam latar belakang dan pemahaman mengenai konsep halal khususnya jika diterakpan dalam industri pariwisata. Pada umumya wisatawan akan mencari produk halal yang terkait dengan makanan. Dalam hal ini wisatawan akan melakukan pencarian secara sederhana dan cepat tentang warung atau restoran mana yang memiliki produk halal. Hal ini sebagaimana diungkapkan Nency wisatawan asal Gorontalo yang menyatakan bahwa

"Nahh.. itu.. yang itu.. itu kan pasti dilihat dulu apakah itu yang ada spanduknya halal.. ooo itu halal.. terus dilihat juga pasti mukaknya.. "ooo kalau kayak orangorang Cina pasti enggak" hehehe.. Cuma ya oo ini yang agak-agak.. ooo ini yang 
Selain logo halal, wisatawan biasa mengidentifikasi kehalalan suatu produk dengan melihat tipikal wajah yang menyiratkan etnis tertentu dan umumnya juga menandakan tentang keyakinan dan agama yang dianutnya. Sebuah hal yang lazim terjadi dalam praktek kehidupan sehari-hari. Walaupun hal ini belum tentu memiliki keakuratan tinggi tentang sajian produk atau jasa yang dihasilkan. Cukup banyak etnis tertentu yang diduga penganut agama atau keyakinan tertentu namun justru sebagai muslim. Sehingga hal ini bisa menimbulkan bias penilaian berawal dari prasangka keyakinan yang dimiliki sebelumya.

Cara lain yang digunakan oleh wisatawan dengan bertanya langsung kepada penjualnya.

"Ini kan ada logo halal terus nanyak "bu ini Islam nggak" hehe.. ada kan teman saya yang satu nggak malu-malu nanya. Biasanya dia yang nanya duluan. "eh kamu maju tanyain toh, hehehe"

Upaya ini dilakukan wisatawan untuk memberikan keyakinan pada dirinya sendiri mengenai kehalalan produk yang akan dikonsumsinya. Keraguan atas kehalalan produk atau jasa yang dkan dipakai akan mempengaruhi pada kemantapan hati untuk mengkonsumsi atau tidak. Jaminan akan kehalalan suatu produk atau jasa terasa dibutuhkan oleh wisatawan.

"Iya penting.. iyaa maksudnya kalau kita kan kayak kalo itu gitu kalau ga ada halal kan ih takut. makan apa lagi sekarang kan sembarang makanan kita tidak tahu prosesnya, apalagi yang sudah live-live di Trans TV itu.. yang ini.. yang aduuhhh.. jadi memang.. "aduh, ternyata di kota-kota besar begini.. aduh" yang apa.. yang daur ulang.. ayamnya udah busuk.. yang udah mati.. jadi kayak ini takut aja jadi iya.. jaga-jaga.. oh.. ternyata di kota besar begitu kalau macam di kita kan, ayamnya pasti.. tangkap di belakang rumah udah ga perlu beli hehe jadi aman.."

Makanan yang halal ini tidak hanya diperuntukkan bagi wisatwan muslim namun juga dapat dikonsumsi dengan baik oleh wisawatan non muslim. Hal ini terjadi karena mengkosumsi produk yang mendasarkan diri pada Syariah bukan hanya memiliki dampak yang baik, namun juga menyehatkan bagi tubuh dan kejiwaan serta akan mampu menjadi sebuah gaya hidup yang sehat (Priyadi, 2016). Sehingga bisa dipastikan bahwa produk dan layanan Syariah dalam pariwisata, termasuk makanan di dalamnya, sebagai produk yang memberikan jaminan keamanan dan kesehatan bagi semua pihak.

Saat ini tayangan tentang gaya hidup termasuk halal banyak bermunculan dan dibahas di media massa. Berbagai tayangan di media massa yang ada juga akan mempengaruhu 
pemikiran dan pen1laian wisatawan sebelum sampai di lolukas 3 Nomor 2 Tahun 2019 2 Wisata. Sehingga wisatawan perlu mendapatkan informasi yang benar dan valid mengenai kehalalan produk atau jasa yang digunakannya selama proses perjalanan wisata mereka lakukan. Tayangantayangan di televisi dengan bebagai ulasan menarik seputar destinasi wisata dan juga kuliner yang ada di dalamnya menjadi daya tarik besar bagi masyarakat. Akhir-akhir ini, wisata bukan lagi sekedar keinginan sekunder semata, namun sudah menjadi kebutuhan dan gaya hidup yang wajib untuk dipenuhi.

Terkait dengan makanan halal ini, peran media cukup besar untuk memberikan informasi kepada masayarakat. Dissy, kru galeri halal AdiTV menyampaikan

"misalnya ada yang bilang ini Chinese Food, ini katanya haram, padahal sebenernya enggak.. itu kan cuman kabar buruk aja. Akhirnya kita informasikan dll."

Media massa memiliki kontribusi memberikan informasi yang mampu mendukung tercapainya wisata halal di suatu daerah. Melalui informasi yang ditayangkan dimungkinkan menjadi sumber referensi acuan masyaralat untuk mengetahui banyak hal yang diperlukan terkait perjalanan wisata. Media massa bisa menjadi salah satu sumber peneguh keyakinan yang telah dimiliki oleh wisatawan. Ataupun sebaliknya media massa mampu menjadi counter informasi yang kurang tepat tentang isu kehalalan menyangkut produk atau jasa tertentu yang menjadi polemic dan akhirnya menjadikan keraguan calon wisatawan untuk mengkonsumsinya.

Wisatawan muslim sebagai konsumen yang berjumlah besar, tidak bisa dikesampingkan begitu saja dalam pemasaran makanan. Hal ini tidak hanya di Indonesia saja, namun kesadaran akan pentingnya makanan halal dalam menunjang pariwisata juga sudah dialami oleh negara lain di dunia. Mengutip data dari PEW Forum yang diadakan pada tahun 2010 (Yuswohadi, 2014) disebutkan bahwa jumlah konsumen muslim mencapai 1,62 miliar orang atau setara dengan $23 \%$ dari total populasi penduduk dunia. Dengan pasar sebesar itu dalam World Halal Forum 2010 dilaporkan nilai makanan halal yang didistribusikan di seluruh dunia sebesar USD 662 miliar. Hal ini menunjukkan dari sisi makanan saja potensi pasar untuk makanan halal sangat besar. Apabila ditambah dengan peluang pasar yang tersedia di sektor lain yang mendukung pariwisata, maka akan diperoleh jumlah yang jauh lebih besar. 
Yogyakarta dikenal sebagai kota yang sarat dengan budaya. Bebagai aspek kehidupan dijalankan sedemikian rupa oleh masyarakatnya masih banyak yang mengacu pada budaya yang dianut dan berlaku di masyarakat. Atraksi atau seni pertunjukan yang disuguhkan oleh para pelaku wisata di Yogyakarta hanya merupakan salah satu bagian dari budaya itu sendiri. Hal ini yang pertama kali wisatawan cari di daerah asalnya sebelum mereka berkunjung ke Yogyakarta. Wisatawan mencari informasi dari berbagai sumber yang bisa diakses. Pada masa kini banyak yang memperoleh informasi melalu platform media sosial tertentu yang tengah menjadi trend. Seperti yang dikemukanan oleh Nency yang menjelaskan

"Mmmmm Jelajah Jogja itu ada.. itu.. apa.. Explore Jogja..".

Melalui platform Instagram yang ada tersebut. Yogyakarta dengan segala keadaan di dalamnya menjadi daya tarik kuat untuk berkunjung bagi wisatawan.

"Iya.. tempat-tempat wisata terbaru kan.. tempat-tempat wisata itu kan.. ada kan.. jadi.. memang kalau favorit tu biasa.. Jogja itu yang paling ngangenin.. hehee Iya.. jalan-jalan makan, iya.. kalau di daerah aku kan, tidak ada makan-makan begini.. ndak ada."

Pertimbangan lain yang dijadikan dasar bagi wisatawan mengunjungi Yogyakata karena harga untuk membeli makanan yang terjangkau. Biaya yang murah untuk biaya sehari-hari untuk para wisatawan adalah makanan. Sehingga apabila harga makanan murah dan halal maka wisatawan akan senang dan merasa nyaman untuk tinggal lama saat kunjungan wisata. "Belakang sini.. Harganya.. jadi oh.. apalagi saya paling suka ikan-ikan Gurameh gitu.. jadi harganya dulu dilihat.. juga.. terjangkau yaa kalau di ini.. pasti kalau lapar tengah malam, ke angkringan situ hehehe". Jadi destinasi wisata yang menarik dengan keadaan budaya, harga yang tidak mahal biaya hidupnya, dan memberikan jaminan kehalalan produk atau jasa yang ditawarkan menjadi pertimbangan penting untuk mengunjungi suatu daerah wisata.

Hal senada juga dikuatkan oleh Dissy, kru Galeri Halal AdiTV yang menyebut bahwa brand kota budaya melekat kuat di Yogyakarta.

"Pariwisata yang memang itu tempat-tempat, karena kita kenal kan Jogjakarta itu kan tempat yang banyak banget adat istiadatnya, dan juga banyak banget tempattempat budayanya.. kita.. kalau menurut aku sih gimana pemerintah atau mungkin kita sebagai warga Yogyakarta sendiri bisa mengenalkan itu ke masyarakat luas, terus abis itu, itu yang harus digali biar tetep lestari gitu lho.. maksudnya kan kalok 
Branding sebagai kota budaya ini sangat menancap dalam benak khalayak. Hal tersbut karena media massa juga telah banyak melakukan penayangan informasi yang reevan dengan branding yang dilakukan. Media massa dalam hal ini televisi memiliki peran penting dalam menyebarluaskan informasi mengenai branding kota maupun wisata halal kepada masyarakat luas khususnya calon wisatawan. Pemberitaan menganai kota atau destinasi wisata akan disesuaikan dengan prinsip jurnalisme. Suatu tempat akan mendapat pemberitaan media karena tempat tersebut memiliki nilai berita (Yananda, $2014: 80$ ).

Khusus terkait dengan branding destinasi halal ini masih belum tergarap dengan optimal atau bisa dikatakan belum tersentuh secara serius.

Kalau menurut aku ya, yang udah dilakuin pemerintah Jogjakarta sendiri, di sini menurut aku sih kalau untuk memang terkait dengan halal dan enggaknya gitu.. memang.. mm gimana yaa? Memang di sini banyak banget branding-branding yang dilakuin sama pemerintah, baik itu tempat-tempat wisata, ataupun mungkin tempattempat kuliner, atau mungkin hal-hal yang berbentuk halal dan lain-lain. Menurut aku sih memang sudah banyak upaya, tapi menurut aku memang belum begitu maksimal. Kenapa di sini.. karena.. gimana yah.. kalau kita berbicara tentang branding, kan kita juga berbicara tentang pemasaran dan lain-lain jugak, dan aku rasa sih pemerintah di sini memang sudah. mmm.. sudah meng-share ke masyarakat.. mempublikasi apa yang mmm. informasi yang untuk masyarakat sendiri, terkait dengan wisata ataupun apa.

Informasi berkaitan dengan wisata halal masih belum terlihat dengan maksimal dilakukan. Banyak informasi yang beragam disampaikan mengenai pariwisata namun belum banyak yang menayangkan informasi seputar wisata halal di Yogyakarta. Informasi yang relevan harus didesain sedemikian rupa untuk mewujudkan destinasi yang ramah terhadap muslim. Media mempunyai peran penting sebagai salah satu agen yang punya pengaruh terhadap tersebarnya informasi mengenai wisata halal.

“Mmmm... kalok realnya sendiri, kalok selaku aku sendiri yang berkecimpung yaa.. termasuk di magazine dan documentary di sini kan memang, di sini tugas aku mmm memberi informasi ke masyarakat "apa itu destinasi wisata, dan jugak referensi kuliner ke masyarakat." Dan kita juga nggak asal kasih informasi jugak.. sebelumnya kita jugak harus riset dulu terlebih dahulu itu tempat seperti apa. Kalaupun memang, contoh, Galeri Halal. Galeri Halal itu kan program kulinernya AdiTV. Sebelum kita melakukan liputan itu kita nggak yang "lah karena ini kekinian kita langsung liput." Tapi aku riset dulu biasanya. dimana biar "apakah ini berbobot untuk masyarakat atau misalnya ini penting untuk disiarkan dan lain-lain. Atau apakah misalnya ini, namanya juga Galeri Halal kan? Kita juga pasti harus memastikan ini halal atau tidak, gitu.." 
dterapkan. Seperti diungkapkan oleh Septi, TIC Dinpar Yogyakarta:

"Kebetulan.. wisata halal itu kan mulai masuk tahun 2016, hampir masuk 2017. Nah, kita juga lagi mengembangkan konsep wisata halal sendiri. Kita masih belajar nih, makanya kemarin kita ke Aceh... itu adalah salah satu mmm kita mau belajar.. Wisata halal di sana tuh seperti apa. Kita mau memperkuat nih, wisata halal di Jogja, karena mulai 2016 itu kan udah tercetus wisata halal di mana-mana. Nah, Kota Jogja ingin mempelopori wisata halal, kayak gitu.."

Pariwisata halal karena masih tergolong baru, maka perlu mendapatkan dukungan dari berbagai pihak yanh terlibat di dalamnya. Pemerintah berupaya untuk menggandeng berbagai pihak pemangku kepentingan pariwisata. Kerjasama dengan media menjadi salah satu upaya yang dilakukan oleh pemerintah untuk mengenalkan wisata halal di Yogyakarta.

"Kalok kita sih biasanya kerjasama sama pemerintah juga pastinya. Nah, namanya televisi kan, pasti pemerintah juga banyak yang branding ke kita juga, kayak maksudnya. jadi kita sebenernya jugak bantu dan dibantu sih. Jadinya, biasanya kalok pemerintah sendiri, kayak dinas-dinas terkait gitu kan ada yang minta AdiTV buat liputan. "Tempat ini diliput dong.."

Wisata halal sendiri di Yogyakarta mulai dirancang dan akan digencarkan belum genap dalam satu tahun di 2018.

"Kalok untuk tahun, bener-bener kita memulai itu 2018 ini. Tahun ini kita udah mulai gencar, kayak mempromosikan bahwa kita mulai ada wisata halal.Kayak gitu, terus kita ngasih.. apa namanya mmm sosialisasi ke tempat-tempat stakeholder maupun tempat-tempat wisata, maupun hotel-hotel, pokoknya yang berkaitan dengan wisata halal sendiri."

Sehingga tak mengherankan jika pemerintah masih perlu untuk melakukan upaya pengenalan dan edukasi mengenai konsep wisata halal yang akan diterapkan di Yogyakarta. Namun demikian menurut Dissy dariAdiTV melihat wisata halal sebagai sebuah industry yang prospektif dan Yogyakarta sudah siap untuk menerapkannya.

"Menurut aku siap banget. Siap banget karena.. karena memang di Jogjakarta sendiri kita banyak pelajar dan banyak banget.. eee.. pelajar mahasiswa gitu lho.. yang mereka juga rata-rata juga muslim menurut aku.. dan mayoritas di Jogjakarta sendiri menurut aku memang muslim"

Dinas Pariwisata Yogyakarta berupaya untuk melakukan branding wisata halal ini tetap sejalan dengan branding yang ada selama ini. Branding yang dilakukan melalui kegiatan travel dialog. 
Itu kan kita tetep mmm.. perannya dinas itu, mm.. mempromosikan dan menguatkan branding itu tuh biar lebih dikenal sama orang, kayak gitu.. Jadi kita bener-bener melakukan kayak apa namanya mmm.. travel dialog atau kita kunjungan wisata ke luar. Promosi.. promosi Kota Jogja sendiri itu kita selalu membawa branding itu sendiri, gitu lho.. Kita memperkenalkan ke wilayah luar itu kayak, kita punya branding nih.. JogjaWelcomesYou sama \#AyokeJogja. Gitu

Harapannya agar terjadi sinergi yang saling mendukung antara konsep wisata halal dan branding yang ditetapkan sebelumnya. Pemerintah juga aktif mengajak para pelaku wisata terkait untuk menggaungkan wisata halal. Pemerintah melakukan roadshow ke kelompok sadar wisata, hotel, dan sebagainya. Sehingga dapat segera terwujud dan memberikan kontibusi bagi perkembangan Yogyakarta.

"Biasanya kampung wisata, itu kita kasih.. terus kelompok sadar wisata juga kita.. kita ngasih sosialisasi juga.. terus yaa, teman-teman stakeholder yaa.. dari hotelhotel, travel agent, restoran, oleh-oleh kayak gitu.. Kita pun juga kayak memberikan sosialisasi bahwa kita akan ada wisata halal nih.. Wisata halal yang.. yang memang sesuai dengan standardisasi mmm itu seperti apa.."

Branding kota sebagaimana dijelaskan oleh Asworth \& Kavaratzis (2007) dalam Yananda (2014:83) menyebutkan branding tempat harus dianggap sebagai proses yang lengkap dan juga kontinu serta saling terkait dengan upaya pemasaran lainnya. Penjelasan ini mengindikasikan bahwa upaya branding kota atau destinasi wisata perlu melibatkan berbagai pihak yang berkepentingan. Proses yang dilakukan secara terus menerus berkelanjutan dengan berbagai macam tema yang tetap mengacu pada identitas kota yang ditetapkan. Berbagai event promosi dapat diciptakan dalam upaya untuk mendukung citra positif yang dimaksud. Pemanfaatan tools of communication yang bervariatif sangat diperlukan. Beragam platform komunikasi dipilih beerdasarkan pada perilaku segmen masyarakat yang menjadi targetnya. Isu mengenai kota budaya dan sebagai daerah tujuan wisata halal perlu mendapatkan perhatian dari sisi konten informasi. Selain upaya pembenahan sarana dan prasarana yang relevan dengan konsep wisata halal terus diupayakan dilengkapi.

\section{CLOSING}

Berdasarkan temuan data yang diperoleh dapat disimpulkan sebagai berikut, pelaku wisata melihat wisata halal sebagai sebuah peluang namun belum memiliki gambaran informasi detail mengenai penerapannya seperti apa di lapangan. Masing-masing pihak berupaya mencari dan memahami sendiri menegenai konsep halal dalam pariwisata Yogyakarta. Branding Yogyakarta sebagai kota budaya masih melekat kuat. Sehingga konsep wisata daerah tujuan wisata halal dikhawatirkan akan berbenturan dengan persoalan budaya 
yang berlaku di masyarakat dan para pemangku kepentingan pariwisata Y Y Tahyakarta. Dengan saran untuk mengubah pandangan dan pemahaman mengenai wisata halal maka langkahlangkah berikut dapat ditempuh. Melakukan edukasi secara konsisten kepada segenap pemangku kepentingan pariwisata Yogyakarta dalam menentukan konsep dan implementasi tentang wisata halal. Para pemangku kepentingan perlu duduk Bersama dalam satu forum untuk membahas tentang wisata halal. Menggunakan platform media sosial yang relevan untuk membantu melakukan branding dengan pesan yang konsisten mengenai wisata halal. Semua isi pesan perlu diarahkan menuju pada muara yang sama yaitu wisata halal.

\section{REFERENCES}

Damanik, Janianton (2013). Pariwisata Indonesia : Antara Peluang dan Tantangan, Yogyakarta: Pustaka Pelajar

Janitra, Muhammad Rayhan (2017). Hotel Syariah: Konsep dan Penerrapan, Depok: Raja Grafindo Persada

Moleong J, Lexy. (2001). Metodologi Penelitian Kualitatif, Bandung: Remaja Rosdakarya

Nazir, Moh. (1988). Metode Penelitian, Jakarta: Ghalia Indonesia

Priyadi, Unggul (2016). Pariwisata Syariah : Prospek dan Perkembangan, Yogyakarta: STIM YKPN Utama, I Gusti Bagus Rai (2017). Pemasaran Pariwisata, Yogyakarta: ANDI

Yananda, M. Rahmat, Salamah, Ummi (2014). Branding Tempat: Membangun Kota, Kabupaten, dan Provinsi Berbasis Identitas, Jakarta: Makna Informasi〉

Yuswohadi, Madyani, Dewi, Herdiansyah, Iryan Ali, dan Alim, Ikhwanudin (2014). Middle Class Muslim: Kenali Perubahannya, Pahami Perilakunya, Petakan Strateginya, Jakarta: Gramedia Pustaka Utama 